\title{
Effect of seed treatments and potting medium on seed germination parameters in threatened Stereospermum suaveolens (Roxb.) DC. - A dashmool species
}

\author{
Saxena Hari Om ${ }^{1}$ 凶, Naseer Mohammad ${ }^{2}$, Parihar Samiksha ${ }^{1}$ and Kumar Sant ${ }^{1}$
}

Received: 02.03.2020

Revised: 28.03.2020

Accepted: 31.03.2020

\begin{abstract}
An experiment was conducted to investigate the effect of different seed treatment and potting media on germination percentage and associate parameters in Stereospermum suaveolens, a threatened dashmool species during May, 2019 at Silviculture Nursery of Tropical Forest Research Institute, Jabalpur (Madhya Pradesh). Experimental treatments comprised of twenty treatment combinations consisting of four different seed treatment and five growth mediums. Data on daily seed germination was recorded and used for estimation of final germination percentage (FGP), mean germination time (MGT), coefficient of velocity of germination (CVG), germination rate index (GRI), time spread of germination (TSG), energy period (EP) and peak value of mean germination (PVMG). Critical perusal of analysis revealed that treatment combination 'Sand + Hot Water' was resulted in positive effect on all the characters studied and could be used for mass raising of seedlings of $S$. suaveolens.
\end{abstract}

Key words: growth medium, seed germination, seed treatment, Stereospermum suaveolens

\section{Introduction}

Although forest tree species are generally propagated by seeds, research reports describing standard package of practices for raising health seedlings are limited due to fragmented research (Mng'omba et al., 2007). AOSA (1970) defines germination as the emergence and development from the seed of those essential structures which are indicative of the ability to produce a normal plant under favorable conditions. In forest tree species, mostly seed germination is low due to hard seed coats and dormant seed embryos (Jaiswal and Chaudhary, 2005) and they often fail to germinate even under favourable conditions (Urgenc and Cepel 2001). Published reports suggest that pretreatments like seed soaking in cold or hot water, acid scarification with sulphuric or hydrochloric acid are known to overcome dormancy of seeds (Bedell, 1998). Pre-soaking of seeds in growth regulator like gibberellic acid $\left(\mathrm{GA}_{3}\right)$ and indole acetic acid (IAA) also reported to enhance seed Author's Address

${ }^{1}$ NWFP section, Silviculture, Forest Management \& Agroforestry Division, Tropical Forest Research Institute, Jabalpur (M.P.), India

${ }^{2}$ Genetics and Tree Improvement Division, Tropical Forest Research Institute, Jabalpur (M.P.), India

E-mail.: hariomsaxena81@gmail.com germination percentage (Chauhan et al., 2009). Planting substrate is also reported to have significant effect on overall seed germination percentage and its other associated parameters. Therefore, in nurseries importance is given to substrate for raising seedlings (Jaiswal and Chaudhary, 2005). A suitable substrate is the one which contain numerous air spaces, provides adequate aeration (Thomson, 1992), non-toxic, free from moulds and microorganisms, cost effective and is easy to handle (Agrawal, 1997).

Stereospermum suaveolens (Roxb.) DC. is commonly known as Patala/ Padar, belongs to the family Bignoniaceae. It contains lapachol and lapachonone, which act against dermatitis (Anonymous, 1998). The plant is of immense importance in Indian system of medicine for its pharmacological potential. Various parts of the plant are used in folk medicine for the treatment of diabetes, diuretic, pain, fever, inflammations and asthma but it is the root which is extensively utilized in the preparation of "Dashmoolarista", an established ayurvedic drug for treating general fatigue, oral sores and several gynecological disorders. Roots of the plant also have an anticancer activity. The species has become threatened in the 
wild due to its over-exploitation, unscientific harvesting, loss and fragmentation of habitats. Very fragmented population of $S$. suaveolens is reported in Madhya Pradesh and species has become rare and vulnerable. The reduced seed production caused gradual erosion of its natural populations. The propagation material of this species is mainly seeds and collecting them is a laborious process as their pericarps are winged. The natural regeneration of the species in the wild is very meager due to poor germination rate. Looking to the commercial importance and rare status of this species, the conservation of the species is of utmost importance. Hence, at Tropical Forest Research Institute,

Jabalpur efforts are initiated to conserve this tree species of high economic value. The present study was undertaken to investigate the effect of different seed treatment and potting media on germination percentage and other associate parameters for $S$. suaveolens.

\section{Material and Methods}

The seeds of $S$. suaveolens were collected from Mandla Forest Division, Madhya Pradesh. Twenty treatment combinations consisting of four different seed treatments and five growth mediums were used for the experimentation is given in table 1. For different treatments, the winged pericarp was removed from the seeds and then they were soaked for $24 \mathrm{~h}$ in distilled water, IAA and $\mathrm{GA}_{3}$. For hot water treatment, seeds were soaked in hot water $\left(100^{\circ} \mathrm{C}\right)$ for $15 \mathrm{~min}$ and then transferred to distilled water at room temperature. Growth medium Cocopeat, Soil, Sand, Soil + Manure + Sand (equal ratio1:1:1), Soil + Manure (equal ratio1:1) were used. Experiments were laid out in completely randomized design with two replications. Uniform maintenance and protection measures recorded every day on number of seeds germinated. Final Germination Percentage and other associated germinating parameters were estimated following standard methodology (table 2).

Table 1. Details of treatment combinations used in investigation

\begin{tabular}{|l|l|l|l|}
\hline Treatment No. & Treatment composition & $\begin{array}{l}\text { Treatment } \\
\text { No. }\end{array}$ & Treatment composition \\
\hline T1 & Cocopeat+GA 3 & T11 & Cocopeat+ Distilled Water \\
\hline T2 & Sand+GA 3 & T12 & Sand+ Distilled Water \\
\hline T3 & $($ Soil+Manure $)+\mathrm{GA}_{3}$ & $\mathrm{~T} 13$ & Soil+ Distilled Water \\
\hline T4 & Soil+GA & & Soil+ Distilled Water \\
\hline T5 & $($ Soil+Manure+Sand $)+\mathrm{GA}_{3}$ & $\mathrm{~T} 15$ & (Soil+Manure)+ Distilled Water \\
\hline T6 & Cocopeat+IAA & $\mathrm{T} 16$ & Cocopeat+ Hot Water \\
\hline T7 & Sand+IAA & $\mathrm{T} 17$ & Sand+ Hot Water \\
\hline T8 & $($ Soil+Manure $)+\mathrm{IAA}$ & $\mathrm{T} 18$ & (Soil+Manure) + Hot Water \\
\hline T9 & Soil+IAA & $\mathrm{T} 19$ & Soil+ Hot Water \\
\hline T10 & $($ Soil+Manure+Sand $)+\mathrm{IAA}$ & $\mathrm{T} 20$ & (Soil+Manure+Sand) + Hot Water \\
\hline
\end{tabular}

\section{Results and Discussion}

Estimates of the final germination percentage and germination percentage and associated parameters other associate parameters are presented in Table 3 were varied in different treatment combinations and graphically visualized in Figures 1. Critical indicating effect of the potting medium and seed perusal of the Table 3 revealed that final treatments. Highest value of final germination 
percentage was obtained in T17 (Sand + Hot indicates that speed of germination is higher in T1 Water) i.e. $56 \%$ followed by the $\mathrm{T} 1$ compared to the T17.Germination rate index (GRI) (Cocopeat $+\mathrm{GA}_{3}$ ). Lowest final germination and Germination index (GI) have positive percentage was reported in T14 (Soil + Distilled Water) i.e. 6\%. Mean germination time which is negatively related to the speed of germination (Orchard, 1977) is lower in T1 (Cocopeat $+\mathrm{GA}_{3}$ ) compared to the T17 (Sand + Hot Water). This correlation with each other and indicates higher and faster germination showed higher values in treatment combination of Cocopeat $+\mathrm{GA}_{3}$ i.e. T1 compared to the Sand + Hot Water, although final germination percentage is higher in T17 (Figure 1).

Table 2. Details of germination parameters estimated in present investigation

\begin{tabular}{|c|c|c|c|c|}
\hline $\begin{array}{l}\text { Germination } \\
\text { Parameter }\end{array}$ & Unit & $\begin{array}{l}\text { Formula for } \\
\text { Calculation }\end{array}$ & Description of Formula & Reference \\
\hline $\begin{array}{l}\text { Final } \\
\text { Germination } \\
\text { Percentage } \\
\text { (FGP) }\end{array}$ & $\%$ & $\begin{array}{l}\text { FGP } \\
=\text { Final no. of } \\
\text { seeds } \\
\text { germinated in a } \\
\text { seed lot } \times 100\end{array}$ & - & $\begin{array}{l}\text { Scott et al. } \\
(1984)\end{array}$ \\
\hline $\begin{array}{l}\text { Mean } \\
\text { Germination } \\
\text { Time (MGT) }\end{array}$ & Day & $\begin{array}{l}\text { MGT } \\
=\sum f \cdot x / \sum f\end{array}$ & $\mathrm{f}=$ Seeds germinated on day $\mathrm{x}$ & $\begin{array}{l}\text { Orchard } \\
(1977)\end{array}$ \\
\hline $\begin{array}{ll}\text { Coefficient } & \text { of } \\
\text { Velocity } & \text { of } \\
\text { Germination } & \\
(\mathrm{CVG}) & \end{array}$ & - & $\begin{array}{l}\text { CVG } \\
=\mathrm{N} 1+\mathrm{N} 2+\cdots+\mathrm{N} \\
\mathrm{x} / 100 \times \mathrm{N} 1 \mathrm{~T} 1+\cdot \cdot \\
+\mathrm{NxTx}\end{array}$ & $\begin{array}{l}\mathrm{N}=\text { No. of seeds germinated each day, } \\
\mathrm{T}=\text { No. of days from seeding } \\
\text { corresponding to N }\end{array}$ & $\begin{array}{l}\text { Jones and } \\
\text { Sanders } \\
(1987)\end{array}$ \\
\hline $\begin{array}{l}\text { Germination } \\
\text { Rate Index } \\
\text { (GRI) }\end{array}$ & $\begin{array}{l}(\% / \mathrm{da} \\
\text { y) }\end{array}$ & $\begin{array}{l}\mathrm{GRI}=\mathrm{G} 1 / 1+ \\
\mathrm{G} 2 / 2+\cdots+\mathrm{Gx} / \mathrm{x}\end{array}$ & $\begin{array}{l}\text { G1=Germination percentage } \times 100 \text { at } \\
\text { thefirst day after sowing, } \\
\text { G2=Germination percentage } \times 100 \text { at } \\
\text { thesecond day after sowing. }\end{array}$ & $\begin{array}{l}\text { Esechi } \\
\text { (1994) after } \\
\text { modificatio } \\
\text { n. }\end{array}$ \\
\hline $\begin{array}{l}\text { Germination } \\
\text { Index (GI) }\end{array}$ & - & $\begin{array}{l}\mathrm{GI}=(10 \times \mathrm{n} 1) \\
+(9 \times \mathrm{n} 2) \quad+\cdots+ \\
(1 \times \mathrm{n} 10)\end{array}$ & $\begin{array}{l}\mathrm{n} 1, \mathrm{n} 2 \ldots \mathrm{n} 10=\text { No. of germinated seeds } \\
\text { on the first, second and subsequent } \\
\text { days until the } 10 \text { th day; } 10,9 \ldots \text { and } 1 \\
\text { are weights given to the number of } \\
\text { germinated seeds on the first, second } \\
\text { and subsequent days, respectively }\end{array}$ & $\begin{array}{l}\text { Bench } \\
\text { Arnold et } \\
\text { al. }(1991)\end{array}$ \\
\hline $\begin{array}{l}\text { Time Spread of } \\
\text { germination } \\
\text { (TSG) }\end{array}$ & Day & $\begin{array}{l}\text { TSG }=\text { The time } \\
\text { in days between } \\
\text { the first and last } \\
\text { germination } \\
\text { events occurring } \\
\text { in a seed lot }\end{array}$ & & $\begin{array}{l}\text { Kader } \\
(1998)\end{array}$ \\
\hline
\end{tabular}


Table 3. Germination percentage and other parameters of $S$. suaveolens in different treatment combination of potting media and seed treatments

\begin{tabular}{|c|c|c|c|c|c|c|c|c|c|c|}
\hline \multirow{2}{*}{$\begin{array}{l}\text { Germination } \\
\text { Parameters }\end{array}$} & \multicolumn{10}{|c|}{ Treatments } \\
\hline & T1 & T2 & T3 & T4 & T5 & T6 & T7 & T8 & T9 & T10 \\
\hline FGP & 45.00 & 15.00 & 35.00 & 19.00 & 39.00 & 23.00 & 6.00 & 20.00 & 42.00 & 20.00 \\
\hline MGT & 8.38 & 11.93 & 9.11 & 12.00 & 8.62 & 8.22 & 12.17 & 8.30 & 11.57 & 9.95 \\
\hline CVG & 11.94 & 8.38 & 10.97 & 8.33 & 11.61 & 12.17 & 8.22 & 12.05 & 8.64 & 10.05 \\
\hline GRI & 5.58 & 1.34 & 4.12 & 1.62 & 4.79 & 2.92 & 0.56 & 2.56 & 3.80 & 2.11 \\
\hline GI & 1018.0 & 286.0 & 766.0 & 361.0 & 873.0 & 524.0 & 113.0 & 454.0 & 816.0 & 421.0 \\
\hline TSG & 6.00 & 10.00 & 8.00 & 7.00 & 8.00 & 6.00 & 11.00 & 8.00 & 7.00 & 8.00 \\
\hline
\end{tabular}

\begin{tabular}{|c|c|c|c|c|c|c|c|c|c|c|}
\hline \multirow{2}{*}{$\begin{array}{l}\text { Germination } \\
\text { Parameters }\end{array}$} & \multicolumn{10}{|c|}{ Treatments } \\
\hline & T11 & T12 & T13 & T14 & T15 & T16 & T17 & T18 & T19 & T20 \\
\hline FGP & 23.00 & 9.00 & 21.00 & 6.00 & 20 & 43.0 & 56.0 & 43.0 & 32.0 & 20.0 \\
\hline MGT & 9.52 & 18.56 & 9.62 & 17.33 & 10.1 & 18.3 & 19.0 & 17.7 & 16.8 & 15.9 \\
\hline CVG & 10.50 & 5.39 & 10.40 & 5.77 & 9.901 & 5.5 & 5.3 & 5.7 & 6.0 & 6.3 \\
\hline GRI & 2.53 & 0.49 & 2.30 & 0.35 & 2.080 & 2.4 & 3.0 & 2.5 & 1.9 & 1.3 \\
\hline GI & 494.0 & 112.0 & 449.0 & 82.00 & 418 & 547.0 & 671.0 & 573.0 & 455.0 & 303.0 \\
\hline TSG & 7.00 & 3.00 & 7.00 & 5.00 & 7 & 10.0 & 14.0 & 10.0 & 10.0 & 3.0 \\
\hline
\end{tabular}

Where, T1-Cocopeat+GA3, T2-Sand+GA3, T3-(S+M)+GA3, T4-Soil+GA3, T5-(S+M+S)+GA3, T6-Cocopeat+IAA, T7-Sand+IAA,T8-(S+M)+IAA, T9Soil+IAA, T10-(S+M+S)+IAA, T11-Cocopeat+Distilled Water, T12-Sand+Distilled Water, T13-S+M+Distilled Water, T14-Soil+Distilled Water, T15S+M+S+Distilled Water, T16-Cocopeat+Hot Water, T17-Sand+ Hot Water, T18- S+M+ Hot Water, T19-Soil+Hot Water, T20-S+M+S+ Hot Water 
Effect of seed treatments and potting medium on seed germination
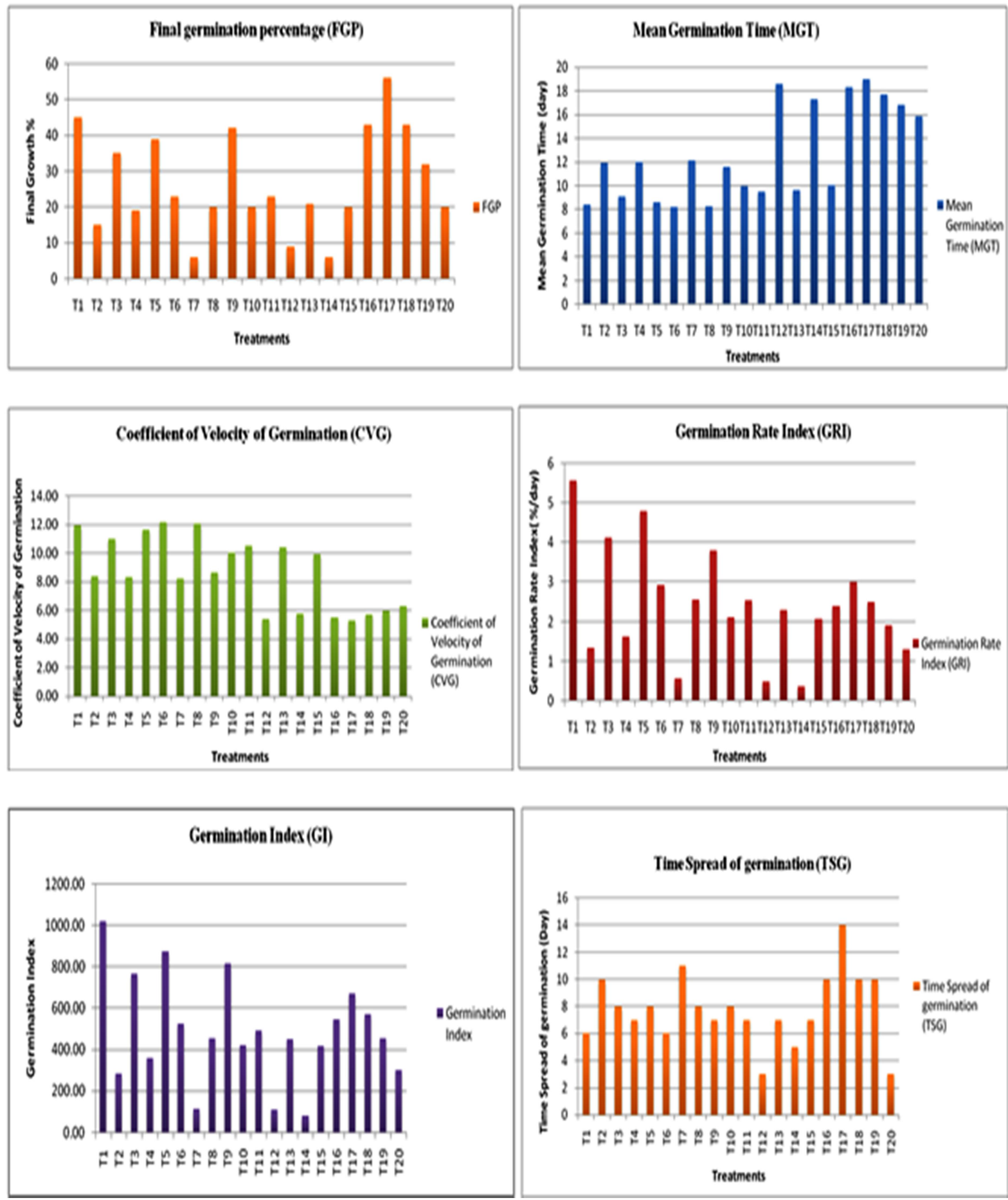

Figure 1. Graphical presentation of the estimates of final germination percentage and other germination parameters under different treatment combination of potting media and seed treatments.

[Where, T1-Cocopeat+GA3, T2-Sand+GA3, T3-(S+M)+GA3, T4-Soil+GA3, T5-(S+M+S)+GA3, T6-Cocopeat+IAA, T7Sand+IAA,T8-(S+M)+IAA, T9-Soil+IAA, T10-(S+M+S)+IAA, T11-Cocopeat+Distilled Water, T12-Sand+Distilled Water, T13-S+M+Distilled Water, T14-Soil+Distilled Water, T15-S+M+S+Distilled Water, T16-Cocopeat+Hot Water, T17Sand+ Hot Water, T18- S+M+ Hot Water, T19-Soil+Hot Water, T20-S+M+S+ Hot Water] 


\section{Saxena et al.}

\section{Conclusion}

It may be concluded that under the constraints i.e. limitation of time, nursery space, etc, treatment combination of 'Cocopeat+GA3' may be adopted for raising the seedlings, whereas, under no constraints of space, time i.e. when one is able to maintain the germination trial for longer period, treatment combination of 'Sand + Hot Water' is suggested.

\section{Acknowledgements}

Authors are grateful to the Director, TFRI, Jabalpur for providing necessary facilities for the experimentation. Authors are equally grateful to the Madhya Pradesh Council of Science and Technology, Bhopal for providing financial support in form of the project (ID: 245).

\section{References}

Agrawal, R.L. (editor). 1997. Seed Technology. Oxford and IBH Publishing, New Delhi. 829 pp.

Anonymous. 1998. Wealth of India. Publication and Information Directorate, CSIR, New Delhi, India.

Association of Official Seed Analysts. 1970. Rules for testing seeds. Proc. AOSA Anal. 60: 1-116.

Bedell, P.E. 1998. Seed Testing. Seed Science and Technology (Indian Forestry Species), : 218-222.

Bench A.R., Fenner, M. and Edwards, P. 1991. Changes in germinability, ABA content and ABA embryonic sensitivity in developing seeds of Sorghum bicolor (L.) Moench induced by water stress during grain filling. New Phytologist, 118: 339-347.
Chauhan, J.S., Tomar Y.K., Singh N.I., Ali S. 2009. Effect of growth hormones on seed germination and seedling growth of black gram and horse gram. Journal of American Science, 5: 79-84.

Esechie, H. 1994. Interaction of salinity and temperature on the germination of sorghum. Journal of Agronomy and Crop Science, 172: 194-199.

Jaiswal, P. and Chaudhary, S. 2005. Germination behaviour of some trees and grasses of arid lands. Bulletin of the National Institute of Ecology, 15: 201-205.

Jones, K. and Sanders, D. 1987. The influence of soaking pepper seed in water or potassium salt solutions on germination at three temperatures. Journal of Seed Technology, 11: 97-102.

Kader (Al-Mudaris), M., Omari, M. and Hattar, B. 1998. Maximizing germination percentage and speed of four Australian indigenous tree species. Dirasat Agricultural Sciences, 25: 157-169.

Mng'omba S.A., du Toit, E.S. and Akinnifesi, F.K. 2007. Germination characteristics of tree seeds: spotlight on Southern African tree species. Tree Forestry Sci. Biotechnol., 1: 20-29.

Orchard, T. 1977. Estimating the parameters of plant seedling emergence. Seed Science and Technology, 5: 61-69.

Scott, S., Jones, R. and Williams, W. 1984. Review of data analysis methods for seed germination. Crop Science, 24: 1192-1199.

Thomson, J.R. 1992. Testing for germination capacity and vigour. In: Thomson J.R. (ed) An Introduction to Seed Technology. Leonard Hill Publisher, London, pp. 198-22

Urgenc, S. and Cepel, N. 2001. Species Selection for Afforestations: Practical Fundamentals of Sowing and Planting. TEMA foundation. Publication no.33, Istanbul. 